\title{
Residual Metal Contamination of the Ecosystem in the Lower Course of the Jihlava River
}

\author{
Petr Spurný ${ }^{1}$, Jan Mareš ${ }^{1}$, Josef Hedbávný ${ }^{2}$, Ivo Sukop ${ }^{1}$ \\ ${ }^{1}$ Department of Fisheries and Hydrobiology \\ ${ }^{2}$ Department of Chemistry and Biochemistry \\ ${ }^{1,2}$ Faculty of Agronomy, Mendel University of Agriculture and Forestry Brno, \\ Czech Republic \\ Received September 16, 2008 \\ Accepted March 9, 2009
}

\begin{abstract}
In November 2001, October and November 2002, the concentrations of $\mathrm{Hg}, \mathrm{Cd}, \mathrm{Pb}, \mathrm{Cr}, \mathrm{Cu}$, $\mathrm{Zn}$ and $\mathrm{Ni}$ were determined in four localities of the lower course of the Jihlava River (Czech Republic). The river water, sediments of the riverbed, zoobenthos and tissues of the fish (gill, gonad, skin, dorsal muscle) were analysed. The chub (Leuciscus cephalus) was used as the ichthyo-indicator. At the same time, the stability of the fish community was evaluated using electrofishing and applying basic ichthyological methods. The work links up with previous investigation of the upper course of the Jihlava River (three localities) carried out by the authors in the same way in 1999. The aim of present study was the completion of previous investigation in the whole longitudinal river profile by monitoring selected heavy metals. The highest $\mathrm{Cr}(14.290$ - $77.070 \mathrm{mg} / \mathrm{kg}), \mathrm{Zn}(13.600-92.930 \mathrm{mg} / \mathrm{kg})$ and $\mathrm{Ni}$ concentrations $(12.290-36.680 \mathrm{mg} / \mathrm{kg})$ were found in sediments and their highest loading by all of the monitored metals (without Ni) was detected in the last downstream locality (Pohořelice). Zoobenthos was most contaminated by $\mathrm{Zn}$ and $\mathrm{Cu}(7.480-62.690$ and $8.050-21.810 \mathrm{mg} / \mathrm{kg})$. In the body tissues of the chubs, the highest concentrations of $\mathrm{Cd}, \mathrm{Hg}, \mathrm{Cu}, \mathrm{Zn}$ and $\mathrm{Ni}$ were determined in the gills, while $\mathrm{Pb}$ was also high in gills but also in gonads, the skin and in the muscle tissue. Concentrations of the analysed metals in the chub muscle were (in $\mathrm{mg} / \mathrm{kg}$ ): $\mathrm{Hg} 0.040 \pm 0.014-0.133 \pm 0.063, \mathrm{Cd} 0.003 \pm 0.002-0.010$ $\pm 0.004, \mathrm{~Pb} 0.045 \pm 0.038-0.768 \pm 0.038, \mathrm{Cr} 0.046 \pm 0.023-0.106 \pm 0.092, \mathrm{Cu} 0.203 \pm 0.123$ $-0.634 \pm 0.194, \mathrm{Zn} 4.25 \pm 0.84-6.69 \pm 2.95$ and Ni $0.062 \pm 0.018-0.103 \pm 0.030$. Significant differences in the chub muscle were found concerning $\mathrm{Hg}, \mathrm{Pb}, \mathrm{Cu}(P<0.01)$ and $\mathrm{Cd}(P<0.05)$. Taking into consideration the actually valid FAO/WHO limits for human consumption of chub muscle from the investigated river section, only $\mathrm{Hg}$ (PTWI $2.3 \mathrm{~kg}$ in locality 7) and Pb (PTWI $2.0 \mathrm{~kg}$ in locality 4) could constitute some risk for human health. The index of diversity of the fish community was $0.825-2.110$, equitability index $0.380-0.793$, abundance $312.6-2,106.5$ fish/ha and biomass $46.7-451.5 \mathrm{~kg} / \mathrm{ha}$. The water quality was characterized as betamesosaprobic (saprobity index $1.77-2.18$ ). The results of the study reveal detailed ecological data concerning heavy metals contamination of the whole Jihlava River ecosystem (water, sediment, zoobenthos, fish). The outcome of this study extends our knowledge about metals accumulation in different fish tissues (gill, gonad, skin and muscle).
\end{abstract}

Stream environment, residual metal pollution, zoobenthos, fish tissues, chub (Leuciscus cephalus)

In the Czech Republic, the former anthropogenic pollution still severely impairs the environment of the fish and, along with the disastrous mortality rate, causes chronic environmental stress with grave consequences for the physiological functions of the fish organism (Hamilton and Mehrle 1986; Hinton and Laurén 1990). Contributing to this phenomena, the occurrence of heavy metals, along with strong eutrophication, constitutes a serious problem (Hughes 1981; Smart 1981). Heavy metals are subjected to cause bioaccumulation in the food chain (Keck 1980). At the top of the food chain are fish, particularly predatory fish and long-living benthophagous species. In ecological terms, fish are irreplaceable bio-indicators of the degree of damage of the water environment (Adams 1990; Thomas 1990). Elevated levels of heavy metals in aquatic organisms, especially 
fish, represent both an ecological and human health concern. Thus the comsumption of contaminated fish is the primary route of these metals to humans and piscivorous wildlife. At the present time about 350,000 anglers are registered in the Czech Republic (3\% of Czech population) who catch between 4,000 and 5,000 tons of fish every year in surface streams and consume these fish at home.

In the Czech Republic, heavy metal distribution in aquatic ecosystems is systematically monitored only during the past 15 years. Svobodová et al. (1993) monitored foreign substances in fish of the Labe (Elbe) River. Žlábek et al. (2005) studied mercury content of fish from Elbe River and its tributaries. Svobodová et al. (1999) published data on the bioaccumulation of mercury in various fish species from the Orlík and Kamýk reservoirs on the Vltava River and data of metal contamination of brown trout in Tichá Orlice River (Svobodová et al. 2004). Heavy metal contamination of the Loučka River ecosystem was assessed by Vítek et al. (2007). The content of mercury in the basic components of the ecosystem and in the fish muscles of the Jihlava River (near Hrubšice and Mohelno) was firstly studied by Peňáz et al. (1979, 1980). Spurný and Mareš (1991) monitored the concentration of $\mathrm{Zn}, \mathrm{Cr}, \mathrm{Pb}, \mathrm{Cd}$ and $\mathrm{Hg}$ in seven fish species of the Jihlava River (Dalešice and Mohelno reservoirs). Peňáz et al. (2002) determined heavy metal concentration (As, $\mathrm{Cd}, \mathrm{Hg}, \mathrm{Pb}, \mathrm{Cr}, \mathrm{Ni}, \mathrm{Cu}, \mathrm{Zn}$ ) in muscles of barbel (Barbus barbus) from three sites of the Jihlava River (Hrubšice, upstream and downstream the effluents from the sewage plant of the Třebíč city). Spurný et al. (2002) studied the concentrations of $\mathrm{Hg}, \mathrm{Cd}, \mathrm{Pb}, \mathrm{Cr}, \mathrm{Cu}$, $\mathrm{Zn}$ and $\mathrm{Ni}$ in three sampling sites of the upper course of the Jihlava River (between river kilometers 156.7 and 92.1). The river water, sediments of the riverbed, zoobenthos samples and fish body tissues of chub (gill, gonad, skin, dorsal muscle) were analysed. Contents of total mercury and mercury species (methylmercury - $\mathrm{MeHg}$, inorganic mercury $-\mathrm{Hg}^{2+}$ ) were determined by Houserová et al. (2006) in Moravian rivers Jihlava, Bečva, Loučka and Dyje. Five fish tissues (muscle, gill, liver, kidney and skin) of chub, zoobenthos, sediments and water samples were analysed.

The aim of this study was to complete the evaluation of the distribution of heavy metals in the ecosystem in the lower course of the Jihlava River, started in 1999 in three localities of the upper section of the river (Spurný et al. 2002). Four sampling sites were selected of the lower course of the river (between river kilometers 47.3 and 13.1, transition between barbel and bream zone) which flows through important town and industrial agglomerations and intensive agriculture. The concentrations of $\mathrm{Hg}, \mathrm{Cd}, \mathrm{Pb}, \mathrm{Cr}, \mathrm{Cu}, \mathrm{Zn}$ and $\mathrm{Ni}$ were monitored in samples of the water, sediments of the river bottom, composite samples of the zoobenthos and in selected body tissues of the chub (Leuciscus cephalus). At the same time we studied the species diversity and ecological stability of the entire fish community in the river section.

\section{Materials and Methods}

Throughout November 2001, October and November 2002, we conducted systematic ichthyological research by means of electrofishing in four localities of the lower course of the Jihlava River to determine the abundance, biomass and species diversity [diversity index according to Shannon and Weaver (1963) and equitability index according to Sheldon (1969)] of the fish community. From each locality, 7 individual samples of the chub were taken for laboratory analyses of heavy metals. At the same time we used portable equipment to measure water temperature, $\mathrm{pH}$ value, conductivity and concentration of dissolved oxygen. For follow-up laboratory analyses of heavy metal concentrations we took samples of the water, sediments of the river bottom and composite samples of the zoobenthos. Zoobenthos was furthermore sampled to assess the degree of the saprobity based on saprobity indexes of the found species.

The monitored river section is characterized to be a barbel zone in transition to bream zone, for the most part with fast flowing water, stony to gravel bottom, in places with sandbanks and silts in the river bottom. The width of the riverbed ranges between 16.7 and $19.4 \mathrm{~m}$. Locality No. 4 (river kilometre 47.3 ) is located in the highest altitude near Hrubšice village downstream the Dalešice and Mohelno reservoirs and the quality of the water is relatively high. Locality No. 5 (river kilometre 36.0) is situated downstream below the industrial town Ivančice (9,400 population; engineering and textile industries). Locality No. 6 (river kilometre 31.0) is located 


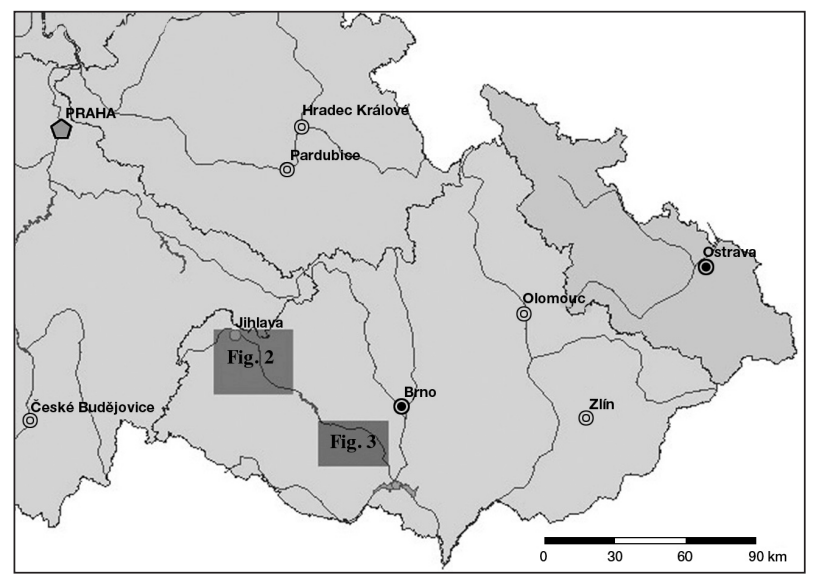

Fig. 1. Location of the Jihlava river sampling area

near Nové Bránice village in intensive agricultural region. Locality No. 7 (river kilometre 13.1) was chosen at the downstream end of the small town Pohorelice (4,500 population, engineering and food industries). A one-day excursion was devoted to reach each of these 4 localities.

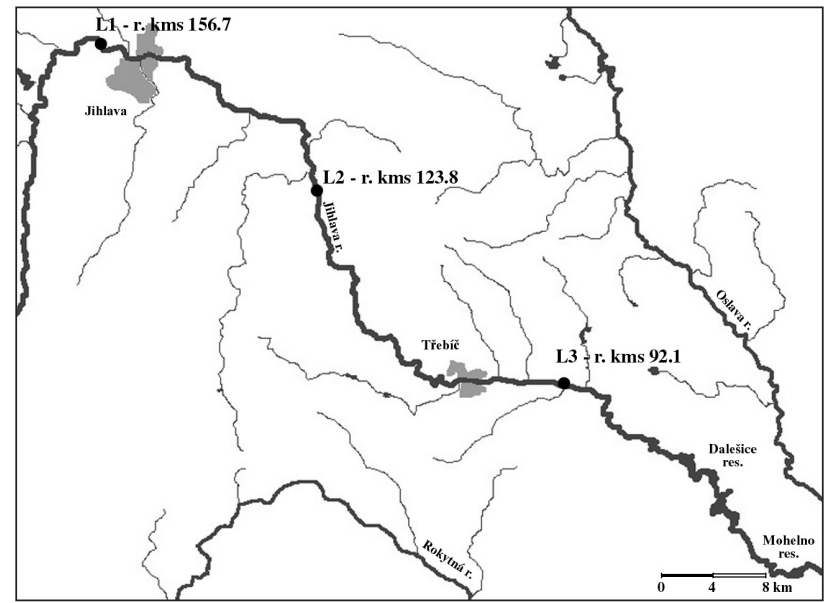

Fig. 2. Sampling sites upstream of Dalešice and Mohelno reservoirs (Spurný et al. 2002)

Samples of the fish tissues for heavy metal analyses were taken into the laboratory immediately after returning from the field excursions. For the individual assessment of heavy metals, samples of the dorsal muscle without skin, gill tissue (cut off from the gill arch), gonads and skin without scales were taken from 7 chubs from each locality. These tissue samples were immediately frozen and kept at a temperature of $-18{ }^{\circ} \mathrm{C}$ together with the water, sediment and zoobenthos samples until analysis. To determine the age of the chubs, 5-8 scales were taken from each fish.

The concentration of heavy metals was analysed after dry mineralising of the fish tissues and sediments using the Czech mineralising equipment APION (producer Tessek Prague). Dry mineralising consists in drying the sample in special bowls at $105^{\circ} \mathrm{C}$ for 2 hours. After cooling the bowls were transferred to the mineralising oven where the samples were incinerated in a mixture of oxidation gases $\left(\mathrm{NO}_{\mathrm{x}}, \mathrm{O}_{3}, \mathrm{O}_{2}\right)$ for 12 hours under programcontrolled temperatures increasing from 20 to $400{ }^{\circ} \mathrm{C}$. The mineralised samples were then placed into a solution of $2.00 \mathrm{~mol} / 1 \mathrm{p} . \mathrm{a} . \mathrm{HNO}_{3}$, filtrated and the solution adjusted to $25 \mathrm{ml}$. 


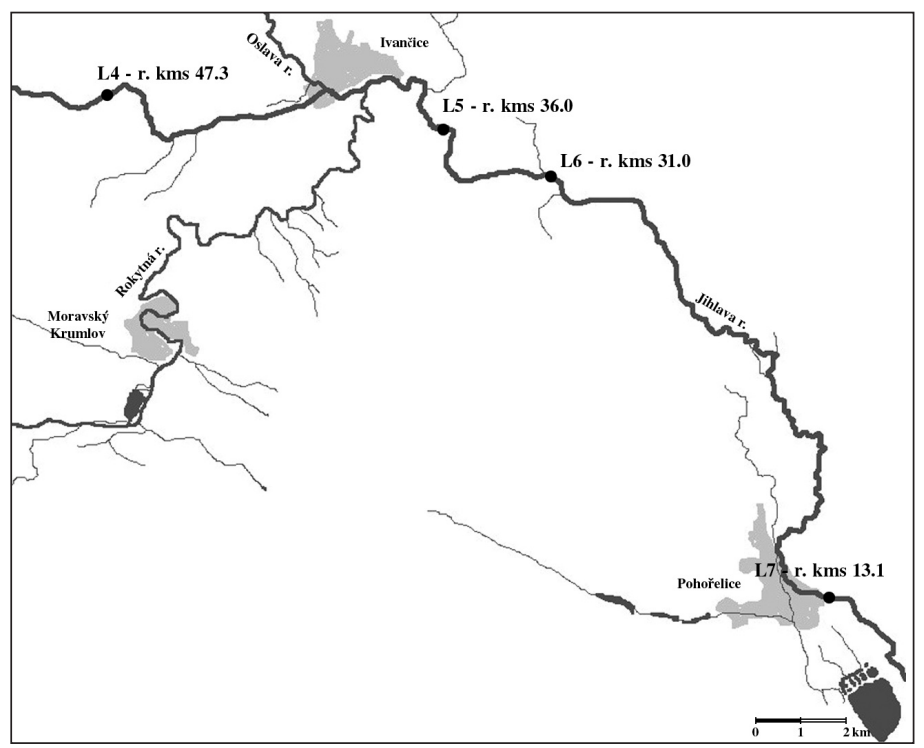

Fig. 3. Sampling sites downstream of Dalešice and Mohelno reservoirs

Mercury was analysed directly in the samples of water, sediments, zoobenthos and fish tissues on a TMA 254 apparatus (Trace Mercury Analyzer, producer VŠCHT Prague, with a detection limit of $\mathrm{Hg} 0.001 \mu \mathrm{g} / \mathrm{kg}$ ) where sample mineralising is part of the analytical process.

Concentrations of $\mathrm{Cd}, \mathrm{Pb}, \mathrm{Cr}, \mathrm{Cu}, \mathrm{Ni}$ and $\mathrm{Zn}$ in the samples were analysed by the AAS method with electrothermal atomisation on the SPECTR AA-30 apparatus (producer Varian Australia, with detection limits of: Cd $0.005 \mu \mathrm{g} / 1, \mathrm{~Pb} 0.100 \mu \mathrm{g} / \mathrm{l}, \mathrm{Cr} 0.020 \mu \mathrm{g} / \mathrm{l}$, Ni $0.080 \mu \mathrm{g} / \mathrm{l}$ ) with electro-thermal atomiser GTA-96. The same method was used to determine the elements in the mineralised sediments, zoobenthos and fish tissues, with the exception of $\mathrm{Cu}$ and $\mathrm{Zn}$, which were determined using the method of flame AAS on the AA 3000 apparatus (producer Perkin Elmer USA, with detection limits of: $\mathrm{Cu} 2.0 \mu \mathrm{g} / 1, \mathrm{Zn} 10.0 \mu \mathrm{g} / \mathrm{l}$ ). A deuterium lamp (on the grounds of interferences caused by the matrix) was used in both apparatuses and for elements determined by the AAS method to correct the background. Standards KS 1014 (the mixture of wheat and soya meal) and KS 1015 (fish meal) from ÚKZÚUZ Brno were used to verify the analytical methods of heavy metals.

The resulting concentrations of heavy metals in the body tissues of the chub were statistically processed (the same type of tissues among all of localities) using analysis of variance (ANOVA) followed by the method of Scheffe. The results are presented as mean values and standard deviation (mean values $\pm \mathrm{SD}$ ).

\section{Results}

Table 1 gives the basic characteristics of the water environment of the studied localities of the Jihlava River. In all the localities the concentrations of dissolved oxygen and $\mathrm{pH}$ value of the water ranged within physiological values normal for fish species of the barbel zone. The water conductivity, characterising the content of dissolved substances, increased from downstream river with $50.4 \mathrm{mS} / \mathrm{m}$ in locality 4 to $56.5 \mathrm{mS} / \mathrm{m}$ in locality 5 (downstream the town Ivančice), then moderately decreased to $53.0 \mathrm{mS} / \mathrm{m}$ in locality 6 and $54.5 \mathrm{mS} / \mathrm{m}$ in locality 7 , respectively. The saprobic index, characterising the trends of organic contamination ranged in investigated river section from 1.77 in locality 5 to 2.18 in locality 7 . The water quality of all the localities was classified to be betamesosaprobic. In this river section the fish community was relatively stable, with the occurrence of 12 fish species from 5 families (Salmonidae, Thymallidae, Esocidae, Cyprinidae, Lotidae). The diversity index ranged from 0.825 to 2.110 , equitability index from 0.380 to 0.793 , abundance from 312.6 to 2,106.5 fish/ha and biomass from 46.7 to $451.5 \mathrm{~kg} / \mathrm{ha}$, with the best ichthyological indicators in the locality 4 near Hrubšice village (Table 2). 
Table 1. Environmental characteristics of the investigated course of the Jihlava River

\begin{tabular}{|c|c|c|c|c|c|c|c|}
\hline $\begin{array}{c}\text { Section } \\
(\mathrm{r} . \mathrm{kms})\end{array}$ & $\begin{array}{c}\text { Sampling } \\
\text { date }\end{array}$ & \multicolumn{2}{|c|}{$\begin{array}{c}\text { Temperature }\left({ }^{\circ} \mathrm{C}\right) \\
\text { air }\end{array}$} & $\mathrm{pH}$ & $\begin{array}{c}\text { Oxygen } \\
(\mathrm{mg} / \mathrm{l})\end{array}$ & $\begin{array}{c}\text { Conductivity } \\
(\mathrm{mS} / \mathrm{m})\end{array}$ & Saprobity \\
\hline $\begin{array}{c}4 \\
(47.3)\end{array}$ & 7.11 .2001 & 11.0 & 11.6 & 8.7 & 11.13 & 50.4 & $\begin{array}{c}1.97 \\
\text { betameso }\end{array}$ \\
\hline $\begin{array}{c}5 \\
(36.0)\end{array}$ & 6.11 .2001 & 13.0 & 9.5 & 8.2 & 11.74 & 56.5 & $\begin{array}{c}1.77 \\
\text { betameso }\end{array}$ \\
\hline $\begin{array}{c}6 \\
(31.0)\end{array}$ & 31.10 .2002 & 9.0 & 8.0 & 6.3 & 11.81 & 53.0 & $\begin{array}{c}2.10 \\
\text { betameso }\end{array}$ \\
\hline $\begin{array}{c}7 \\
(13.1)\end{array}$ & 30.9 .2002 & 11.0 & 9.6 & 7.2 & 10.58 & 54.5 & $\begin{array}{c}2.18 \\
\text { betameso }\end{array}$ \\
\hline
\end{tabular}

Table 2. Characterization of fish communities in 4 sections of the Jihlava River

\begin{tabular}{|l|c|c|c|c|}
\hline $\begin{array}{l}\text { Section } \\
\text { (river kilometres) }\end{array}$ & $\begin{array}{c}4 \\
(47.3)\end{array}$ & $\begin{array}{c}5 \\
(36.0)\end{array}$ & $\begin{array}{c}6 \\
(31.0)\end{array}$ & $\begin{array}{c}7 \\
(13.1)\end{array}$ \\
\hline number of fish & 178 & 70 & 23 & 29 \\
\hline number of species & 9 & 5 & 5 & 6 \\
\hline $\mathrm{H}^{\prime}$ & 2.110 & 0.825 & 1.841 & 1.805 \\
\hline $\mathrm{E}$ & 0.666 & 0.380 & 0.793 & 0.530 \\
\hline abundance (fish/ha) & 2106.5 & 618.3 & 474.1 & 312.6 \\
\hline biomass (kg/ha) & 451.5 & 175.2 & 94.4 & 46.7 \\
\hline
\end{tabular}

$\mathrm{H}^{\prime}=$ the diversity index (Shannon and Weaver 1963)

$\mathrm{E}=$ the equitablity index (Sheldon1969)
Table 3 shows the analyses of heavy metals in the aquatic environment of the studied river section (water, riverbed sediments, composite samples of the zoobenthos). The concentrations of $\mathrm{Hg}, \mathrm{Cd}, \mathrm{Pb}$, $\mathrm{Cr}, \mathrm{Zn}$, and $\mathrm{Ni}$ were found to be somewhat higher in the locality 4 (downstream the Dalešice and Mohelno reservoirs). The content of $\mathrm{Hg}$ both in the water and sediments gradually

decreased downstream up to locality 7 . However, we detected considerable increases of the concentrations of $\mathrm{Cd}, \mathrm{Pb}, \mathrm{Cr}$ and $\mathrm{Cu}$ in the water of locality 6 (near Nové Bránice village) and of $\mathrm{Cd}, \mathrm{Pb}, \mathrm{Cr}, \mathrm{Cu}, \mathrm{Zn}$ and $\mathrm{Ni}$ in the sediments of the locality $7(\mathrm{~Pb} 10.500$ $\mathrm{mg} / \mathrm{kg}$, Cr $77.070 \mathrm{mg} / \mathrm{kg}$ ). However, this trend was not found in zoobenthos samples because the highest concentrations of analysed metals were detected in locality 4 and decreased considerably downstream.

Table 4 shows the average concentrations of heavy metals in gill, gonad, skin and muscle tissue of the chub. The statutory limit for $\mathrm{Hg}$ valid at the time of sampling

Table 3. Heavy metal concentrations, analysed in the river environment in 4 sections of the Jihlava River

\begin{tabular}{|c|c|c|c|c|c|c|c|c|}
\hline Section & Specimen & $\mathrm{Hg}$ & $\mathrm{Cd}$ & $\mathrm{Pb}$ & $\mathrm{Cr}$ & $\mathrm{Cu}$ & $\mathrm{Zn}$ & $\mathrm{Ni}$ \\
\hline \multirow{4}{*}{4} & water & 1.900 & 0.920 & 4.400 & 1.500 & 4.800 & 13.000 & 2.200 \\
\cline { 2 - 9 } & sediments & 0.055 & 0.063 & 3.477 & 18.990 & 8.776 & 13.600 & 36.680 \\
\cline { 2 - 9 } & zoobenthos & 0.015 & 0.567 & 1.126 & 2.792 & 21.810 & 62.690 & 10.130 \\
\hline \multirow{3}{*}{5} & water & 1.100 & 1.150 & 4.000 & 1.600 & 3.200 & 3.000 & 1.100 \\
\cline { 2 - 10 } & sediments & 0.008 & 0.045 & 4.843 & 14.290 & 4.079 & 16.370 & 12.290 \\
\cline { 2 - 10 } & zoobenthos & 0.019 & 0.069 & 1.423 & 1.280 & 8.050 & 22.070 & 3.190 \\
\hline \multirow{2}{*}{6} & water & 0.110 & 2.000 & 5.000 & 2.600 & 15.000 & 8.000 & 2.700 \\
\cline { 2 - 9 } & sediments & 0.013 & 0.121 & 4.656 & 22.060 & 10.310 & 30.880 & 14.460 \\
\cline { 2 - 9 } & zoobenthos & 0.068 & 0.040 & 0.516 & 1.070 & 9.520 & 7.480 & 0.763 \\
\hline 7 & water & 0.500 & 1.700 & 4.100 & 1.500 & 20.000 & 8.000 & 2.900 \\
\cline { 2 - 9 } & sediments & 0.056 & 0.245 & 10.500 & 77.070 & 24.010 & 92.930 & 29.480 \\
\cline { 2 - 9 } & zoobenthos & 0.024 & 0.218 & 0.620 & 0.292 & 10.950 & 19.730 & 1.368 \\
\hline
\end{tabular}

Heavy metal concentration in water is presented in $\mu \mathrm{g} / \mathrm{l}$, in sediments and zoobenthos in $\mathrm{mg} / \mathrm{kg}$ of the wet matter. 


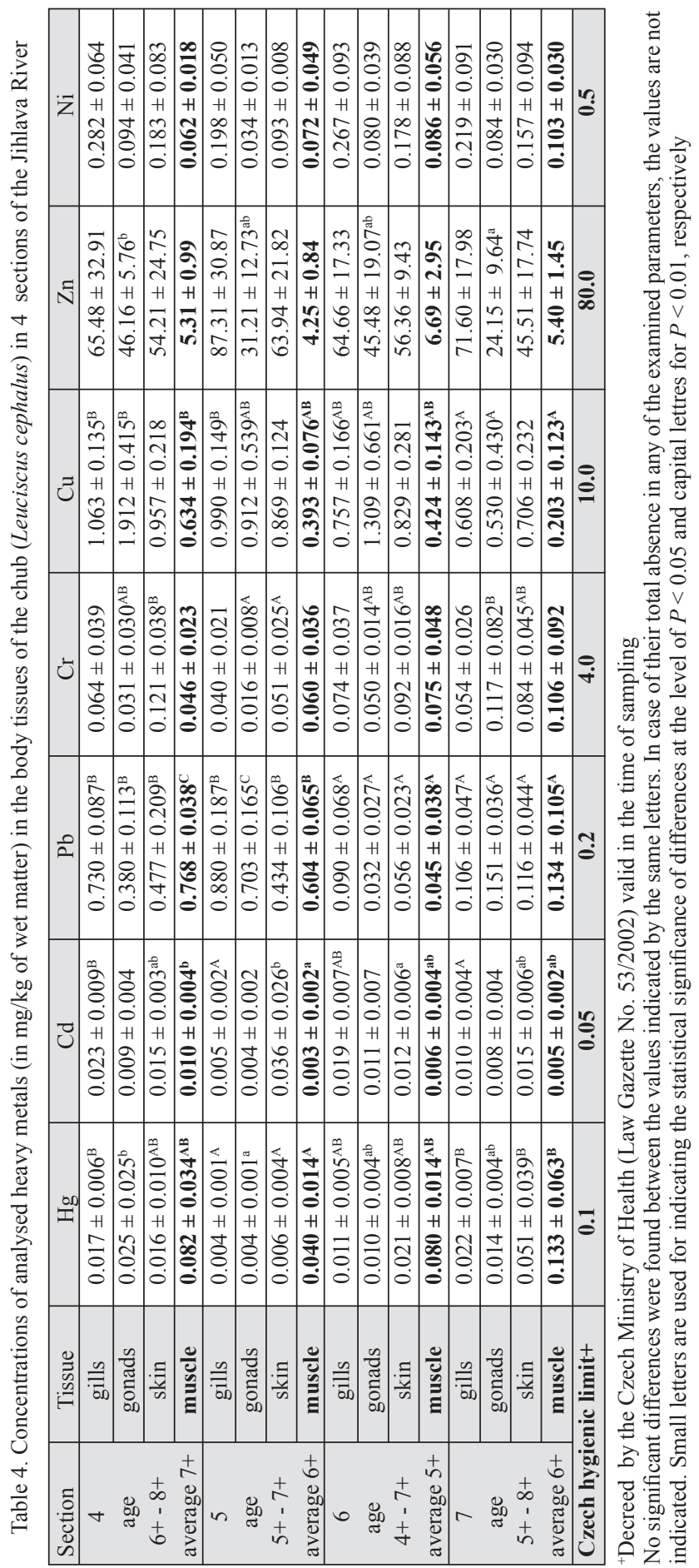

$(0.1 \mathrm{mg} / \mathrm{kg}$ for nonpredatory fish species) in the muscle tissues was slightly exceeded only in locality $7(0.133$ $\mathrm{mg} / \mathrm{kg}$ ) and this value was higher $(P<0.01)$ compared to locality 5 . The limit concentration of $\mathrm{Pb}(0.2 \mathrm{mg} / \mathrm{kg})$ in fish muscle were strongly exceeded in locality 4 ( $0.768 \mathrm{mg} / \mathrm{kg}$, highly significant compared to the other localities) and in locality 5 (0.604 mg/ $\mathrm{kg}$ ). The concentrations of $\mathrm{Cd}, \mathrm{Cr}, \mathrm{Cu}, \mathrm{Zn}$ and $\mathrm{Ni}$ in the muscle tissue did not exceed the statutory limits. The concentrations among the localities did not differ concerning $\mathrm{Cr}, \mathrm{Zn}$ and $\mathrm{Ni}$ but revealed different values for $\mathrm{Cd}(P<0.05)$ and for $\mathrm{Cu}(P<0.01)$.

In the other fish tissues, the statutory limit of $\mathrm{Pb}$ was highly exceeded in locality $4(0.730 \mathrm{mg} / \mathrm{kg}$ in gill, $0.380 \mathrm{mg} / \mathrm{kg}$ in gonad, $0.477 \mathrm{mg} / \mathrm{kg}$ in skin) and also in locality $5(0.880$ $\mathrm{mg} / \mathrm{kg}$ in gill, $0.703 \mathrm{mg} / \mathrm{kg}$ in gonad, $0.434 \mathrm{mg} / \mathrm{kg}$ in skin). The concentrations of the other analysed metals in gill, gonad and skin were below admissible limits.

Considerably higher concentrations of heavy metals (with the exception of $\mathrm{Hg}$ ) were detected in gill tissue of the analysed fish in most of the localities. These data correspond with concentrations found in the water of the localities. Generally, the heaviest contamination of body tissues of the fish with 
heavy metals (except for $\mathrm{Hg}$ and $\mathrm{Cd}$ ) was detected in localities 4 and 5, i.e. downstream below the Dalešice and Mohelno reservoirs and the town Ivančice.

According to the actually valid FAO/WHO limits, the maximum tolerable daily or weekly human intakes of the muscle of chub from investigated river section are included in Table 5. Among the detected metals, only $\mathrm{Hg}$ (PTWI $2.3 \mathrm{~kg}$ in locality 7) and Pb (PTWI $2.0 \mathrm{~kg}$ in locality 4) can constitute some risk for human health.

Table 5. Maximal chub muscle intake from the lower course of the Jihlava River according to FAO/WHO limits (in $\mathrm{kg} / 60 \mathrm{~kg}$ body mass of human consumer)

\begin{tabular}{|c|c|c|c|c|c|c|c|}
\hline Metal & $\mathrm{Hg}$ & $\mathrm{Cd}$ & $\mathrm{Pb}$ & $\mathrm{Cr}$ & $\mathrm{Cu}$ & $\mathrm{Zn}$ & $\mathrm{Ni}$ \\
\hline Limit & 5 & 7 & 25 & - & 500 & 1000 & - \\
$(\mu \mathrm{g} / \mathrm{kg})$ & $\mathrm{PTWI}$ & $\mathrm{PTWI}$ & $\mathrm{PTWI}$ & & PMTDI & PMTDI & \\
\hline Intake & 2.3 & 42.0 & 2.0 & - & 47.3 & 9.0 & - \\
(locality) & $(7)$ & $(7)$ & $(4)$ & & $(4)$ & $(6)$ & - \\
\hline
\end{tabular}

PTWI-provisional tolerated weekly intake, PMTDI-provisional maximum tolerable daily intake

\section{Discussion}

In comparison with the upper course of the Jihlava River (S purný et al. 2002; Hou serová et al. 2006), the concentrations of heavy metals in the aquatic environment of the lower course of the river in general gradually decreased (except for the content of $\mathrm{Cr}, \mathrm{Cu}$ and $\mathrm{Ni}$ in riverbed sediments of locality 7). In comparison with locality 1, the accumulation of $\mathrm{Cr}$ increased in sediments of locality 7 nearly 10 -fold (up to $77.070 \mathrm{mg} / \mathrm{kg}$ ). Increased amounts of metals deposited within sediments mean as a consequence to bear an ecological risk in case of their sudden release from sediments due to hydrological changes. The highest content of analysed metals in zoobenthos samples was detected in locality 4 (downstream the Dalešice and Mohelno reservoirs) which represents the most contaminated locality of the investigated lower section of the river, following the significant pollution of locality 3 (Vladislav) situated upstream these reservoirs. In accordance with this trend, Hou serová et al. (2006) found at the same locality the highest content of total $\mathrm{Hg}$ in the sediment $(0.225$ $\mathrm{mg} / \mathrm{kg}$ in dry matter) and in zoobenthos $(0.265 \mathrm{mg} / \mathrm{kg}$ in dry matter $)$ from the Jihlava River suggesting an influence of Dalešice and Mohelno reservoirs on aquatic fauna. Fish fauna cannot naturally migrate due to dams, therefore fish from the more contaminated upstream area do not appear in the downstream water which is less polluted. In addition, Spurný and Mareš (1991) determined concentrations of $\mathrm{Hg}$ in the muscle of perch (4-5 years old) from the Dalešice reservoir ranging between 0.63 and $0.78 \mathrm{mg} / \mathrm{kg}$ and in the muscle of a 7-year-old roach $0.48 \mathrm{mg} / \mathrm{kg}$. Vítek et al. (2007) found in sediments of the upper and middle course of the Loučka River (right-side tributary of the Svratka River) similar concentrations of $\mathrm{Cd}(0.303 \mathrm{mg} / \mathrm{kg})$ and of $\mathrm{Pb}(12.050 \mathrm{mg} / \mathrm{kg})$, but higher concentrations of $\mathrm{Hg}(0.208 \mathrm{mg} / \mathrm{kg})$ and $\mathrm{Cu}(80.200 \mathrm{mg} / \mathrm{kg})$ and lower contents of $\mathrm{Cr}(36.196 \mathrm{mg} / \mathrm{kg}), \mathrm{Zn}$ $(75.100 \mathrm{mg} / \mathrm{kg})$ and $\mathrm{Ni}(24.980 \mathrm{mg} / \mathrm{kg})$ compared to the investigated section of the Jihlava River. Heavy metal contamination of zoobenthos in the Loučka River (Vítek et al. 2007) is very similar (only maximum concentrations of $\mathrm{Cr}-3.832 \mathrm{mg} / \mathrm{kg}$ and $\mathrm{Cu}-74.300 \mathrm{mg} / \mathrm{kg}$ are higher and that of $\mathrm{Ni}-1.505 \mathrm{mg} / \mathrm{kg}$ is lower) to the Jihlava River.

The content of $\mathrm{Hg}$ in muscle tissue of the chub in locality $4(0.082 \mathrm{mg} / \mathrm{kg})$ was dramatically lower than in locality 3 (Vladislav $-0.136 \mathrm{mg} / \mathrm{kg}$ ) furthermore decreasing in locality 5 $(0.040 \mathrm{mg} / \mathrm{kg})$ and showing a strong increase up to $0.133 \mathrm{mg} / \mathrm{kg}$ in locality 7 . Peňáz et al. (1979) determined the $\mathrm{Hg}$ content in muscle tissue of the chub near Hrubšice (our locality 4) to be within $0.14-0.22 \mathrm{mg} / \mathrm{kg}$. In this locality Peňáz et al. (2002) reported that the concentration of $\mathrm{Hg}$ in the muscle tissue of barbel (age from $3+$ to $9+$ years) ranged from 0.030 to $0.113 \mathrm{mg} / \mathrm{kg}$. Houserová et al. (2006) analysed total $\mathrm{Hg}$ content in chub muscle 
near Hrubšice and revealed a value of $0.135 \mathrm{mg} / \mathrm{kg}$ in dry matter which was 7-times lower compared to the muscle samples from Vladislav $(0.962 \mathrm{mg} / \mathrm{kg}$ in dry matter). Žlábek et al. (2005) published average concentrations of $\mathrm{Hg}$ in chub muscle from Elbe River, Vltava River and Blanice River to be in the range of 0.141 to $1.631 \mathrm{mg} / \mathrm{kg}$ and Svobodová et al. (1993) detected $1.600 \mathrm{mg} / \mathrm{kg}$ of $\mathrm{Hg}$ in perch muscle from Elbe River near Čelákovice. Vítek et al. (2007) determined $0.390 \mathrm{mg} / \mathrm{kg}$ of $\mathrm{Hg}$ in brown trout muscle from Loučka River and Svobodová et al. (2004) detected $0.410 \mathrm{mg} / \mathrm{kg}$ of $\mathrm{Hg}$ in the muscle tissue of the same fish species derived from Tichá Orlice River. In comparison with the above mentioned values from other Czech rivers, the $\mathrm{Hg}$ contamination of chub muscle from Jihlava River seems to be much lower. Comparing the contents of $\mathrm{Pb}$ and $\mathrm{Cr}$ in chub muscle derived from locality 4 with the results of Peňáz et al. (2002) in barbel muscle, Pb contents were 10-fold higher in chub $(0.768 \mathrm{mg} / \mathrm{kg})$ compared with barbel $(<0.050-0.066 \mathrm{mg} / \mathrm{kg})$ and $\mathrm{Cr}$ had 7.5 -times lower concentrations in chub $(0.046 \mathrm{mg} / \mathrm{kg})$ compared to barbel $(0.083-0.345$ $\mathrm{mg} / \mathrm{kg}$ ). Concerning the concentrations of the further analysed metals $(\mathrm{Cd}, \mathrm{Cu}, \mathrm{Zn}$ and Ni) only minor differences were found between chub and barbel. However, we should take into consideration that barbel represents a distinct benthophagous and very slow growing fish species and is assumed also to have a higher bioaccumulation rate for heavy metals. Vítek et al. (2007) found in brown trout muscle from Loučka River average concentrations for $\mathrm{Pb}$ in the range of $0.108-1.010 \mathrm{mg} / \mathrm{kg}$, for $\mathrm{Cr}$ of $0.028-0.073 \mathrm{mg} / \mathrm{kg}$, for $\mathrm{Cu}$ of 0.329 $-0.399 \mathrm{mg} / \mathrm{kg}$ and for $\mathrm{Zn}$ of $3.956-5.801 \mathrm{mg} / \mathrm{kg}$. Svobodová et al. (2004) reported in the upper course of Tichá Orlice River maximum contamination of brown trout muscle by $\mathrm{Cr}$ of $0.081 \mathrm{mg} / \mathrm{kg}$, by $\mathrm{Cu}$ of $0.343 \mathrm{mg} / \mathrm{kg}$ and by $\mathrm{Zn}$ of $4.53 \mathrm{mg} / \mathrm{kg}$. In the case of $\mathrm{Pb}, \mathrm{Cr}$ and $\mathrm{Cu}$ our results are very similar, but the maximum content of $\mathrm{Zn}$ in chub muscle from the Jihlava River $(6.69 \mathrm{mg} / \mathrm{kg})$ was 1.5-times higher compared to that one from the Tichá Orlice River.

Houserová et al. (2006) found the lowest concentrations of total $\mathrm{Hg}$ in gill and skin of all tested chubs. The $\mathrm{Hg}$ content in investigated tissues decreased in the following order: muscle $>>$ kidney $\approx$ liver $>$ skin $\approx$ gill. In our study we found this trend also in tissues of chub (muscle, gill, gonad, skin) for $\mathrm{Hg}$ (muscle $>>$ gill $\approx$ gonads $\approx$ skin). In the case of $\mathrm{Cd}, \mathrm{Pb}, \mathrm{Cr}, \mathrm{Cu}, \mathrm{Zn}$ and $\mathrm{Ni}$ we found the highest contents in gill and skin of the fish derived from all localities. Higher concentrations of these metals (except for $\mathrm{Cr}$ ) were also detected in the gills and skin of chub from the upper course of the river (Spurný et al. 2002). Therefore, analyses of these directly exposed tissues, especially of gills, have a high bio-indicative value for the quality of the aquatic environment, because the pollutants enter the tissues directly, and not via the food chain. The increased contents of $\mathrm{Cu}$ was also recorded in chub gonads from localities $4(1.912 \mathrm{mg} / \mathrm{kg}), 5(0.912 \mathrm{mg} / \mathrm{kg})$ and $6(1.309 \mathrm{mg} /$ $\mathrm{kg})$. The high concentrations of $\mathrm{Pb}$ in gonads from localities $4(0.380 \mathrm{mg} / \mathrm{kg})$ and $5(0.703$ $\mathrm{mg} / \mathrm{kg})$ and of $\mathrm{Cr}$ from locality $7(0.117 \mathrm{mg} / \mathrm{kg})$ might even disturb natural reproduction of fish.

The specific heavy metal pollution of the aquatic environment of the Jihlava River corresponds with their contents in monitored tissues of chub and appears to be relatively high in the upper course of the river, especially downstream to large industrial impacts by the towns Jihlava and Třebíč. The high loading of the ecosystem by heavy metal pollution persists still downstream the Dalešice and Mohelno resevoirs and decreases consecutively downstream to the lower river sections. An important ecological hazard is given by enhanced contents of heavy metals in riverbed sediments of locality 7 (Pohořelice). Generally, downstream the loading of the river by these specific pollutants decreases and corresponds with a trend of decreased organic contamination. The saprobity index gradually decreases from the $1^{\text {st }}$ to the $5^{\text {th }}$ locality with a moderate increase in localities 6 and 7 . In the $3^{\text {rd }}$ locality the alphamesosaprobity converts into betamesosaprobity and persists at this level along the lower course of the river. 
The results of our study did not confirm the assumption that the Jihlava River was generally considered to be one of the most heavily polluted Czech rivers concerning $\mathrm{Hg}$ (Moldán et al. 1990). However, Houserová et al. (2006) found that Hg contamination of muscle samples of chub from Loučka, Dyje and Bečva Rivers were approximately two times lower compared to samples from the Jihlava River (sampling site Vladislav) where also the highest contents were found in sediment and zoobenthos samples. Moreover, our study proved some risk for human consumption of fish caught inthe lower course of the river in the case of $\mathrm{Hg}$ and $\mathrm{Pb}$.

\section{Zbytkové znečištění ekosystému dolního toku řeky Jihlavy těžkými kovy}

V listopadu 2001, ř́ijnu a listopadu 2002 byla zjišt'ována koncentrace $\mathrm{Hg}, \mathrm{Cd}, \mathrm{Pb}, \mathrm{Cr}, \mathrm{Cu}$, Zn a Ni na čtyřech lokalitách dolního toku řeky Jihlavy. Analýzy byly prováděny v říční vodě, sedimentech dna, vzorcích zoobentosu a v tělních tkáních ryb (žábry, gonády, kůže, hřbetní svalovina). Jako ichtyoindikátor byl použit jelec tloušt' (Leuciscus cephalus). Současně byl pomocí elektrolovu a základních ichtyologických metod hodnocen stav rybího společenstva (abundance, biomasa, index diverzity, index ekvitability) a podle druhového složení společenstva zoobentosu zjišstován index saprobity. Cílem sledování bylo dokončit zmapování distribuce těchto polutantů v celém toku řeky Jihlavy, zahájené v roce 1999 autory této studie na třech lokalitách horního toku řeky. Nejvyšší koncentrace Cr $(14,290$ $-77,070 \mathrm{mg} / \mathrm{kg}), \mathrm{Zn}(13,600-92,930 \mathrm{mg} / \mathrm{kg})$ a Ni $(12,290-36,680 \mathrm{mg} / \mathrm{kg})$ byly zjištěny v sedimentech dna, jejichž nejvyšší zátěž všemi sledovanými kovy (s výjimkou Ni) byla detekována na nejníže po proudu ležící lokalitě (Pohořelice). Zoobentos byl nejvíce kontaminován $\mathrm{Zn} \mathrm{a} \mathrm{Cu}(7,480$ - 62,690 a 8,050 - 21,810 mg/kg). V tělních tkáních jelce tlouště byly nejvyšší hodnoty kadmia, olova, mědi, zinku a niklu zjištěny v žábrách, v případě olova také v gonádách, kůži a ve svalové tkáni. Koncentrace analyzovaných kovů ve svalové

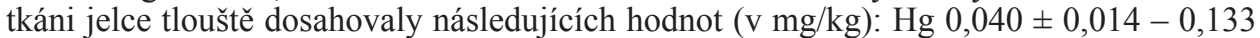

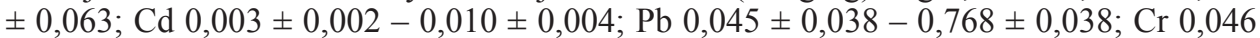
$\pm 0,023-0,106 \pm 0,092 ; \mathrm{Cu} 0,203 \pm 0,123-0,634 \pm 0,194 ; \mathrm{Zn} 4,25 \pm 0,84-6,69 \pm 2,95$ and Ni 0,062 $\pm 0,018-0,103 \pm 0,030$. Vysoce průkazné rozdíly $(P<0,01)$ v koncentraci sledovaných kovů ve svalovině jelce tlouště byly zjištěny $\mathrm{v}$ prŕípadě $\mathrm{Hg}, \mathrm{Pb} \mathrm{a} \mathrm{Cu}, \mathrm{v}$ prrípadě Cd potom průkazné $(P<0,05)$ rozdíly. V souladu s aktuálně platnými limity FAO/WHO pro lidský konzum svaloviny jelce tlouště ze sledovaného říčního úseku pouze rtut' (PTWI 2,3 kg na lokalitě 7) a olovo (PTWI 2,0 kg na lokalitě 4) mohou představovat určité riziko pro lidské zdraví. Index diverzity rybího společenstva dosahoval rozpětí $0,825-2,110$, index ekvitability 0,380-0,793, abundance 312,6-2.106,5 ks/ha a biomasa 46,7-451,5 kg/ha. Kvalita vody byla charakterizována jako betamesosaprobní (index saprobity 1,77 - 2,18).

\section{Acknowledgements}

This study was supported by the Research plan No. MSM6215648905 "Biological and technological aspects of sustainability of controlled ecosystems and their adaptability to climate change", financed by the Ministry of Education, Youth and Sports of the Czech Republic.

\section{References}

Adams SM 1990: Status and use of biological indicators for evaluating the effects of stress on fish. Biological indicators of stress in fish. 8th American Fisheries Society Symposium, Maryland, pp. 1-8

Hamilton SJ, Mehrle PM 1986: Metallothionein in fish: review of its importance in assessing stress from metal contaminants. Trans Amer Fish Soc 115: 596-609

Hinton DE, Laurén DJ 1990: Integrative histopathological approaches to detecting effects of environmental stressors on fish. Biological indicators of stress in fish. 8th. American Fisheries Society Symposium, Maryland, pp. 51-66

Houserová P, Kubáň V, Spurný P, Habarta P 2006: Determination of total mercury and mercury species in fish and aquatic ecosystems of Moravian rivers. Vet Med - Czech 51: 10-110 
Hughes GM 1981: Effects of low oxygen and pollution on the respiratory systems of Fish. Stress And Fish. Academic Press, London and New York, pp. 112-146

Keck G 1980: Relations entre pollution chimique et valeur alimentaire et hygiénique du poisson. Allocation of Fishery Resources FAO, pp. 164-170

Moldán B (Ed.) 1990: Environment of the Czech republic (Evolution and stage up to year 1989) (in Czech). Academia, Prague, $284 \mathrm{pp}$.

Peňáz M, Svobodová Z, Hejtmánek M. Trnková, J 1979: Mercury contents in muscles of fishes from the Jihlava river. Fol Zool 28: 171-176

Peňáz M, Svobodová Z, Hejtmánek M, Trnková J, Wohlgemuth E 1980: Mercury content in the basic components of the ecosystem of the Jihlava river (in Czech with English summary). Bull. of Research Institute of Fishery and Hydrobiology Vodňany, pp. 24-30

Peňáz M, Baruš V, Prokeš M 2002: Concentration of heavy metals and changes in concentrations of the mercury in muscle tissues of the barbel (Barbus barbus) from the river Jihlava (in Czech with English summary). The $5^{\text {th }}$ Czech conference of Ichthyology, Brno, pp. 253-258

Shannon CE, Weaver V 1963: The mathematical theory of Communities. Univ Ilinois Press, Urbana

Sheldon AL 1969: Equitability indices: dependence on the species count. Ecology 50: 466-467

Smart GR 1981: Aspects of water quality producing stress in intensive fish culture. Stress and Fish. Academic Press, London and New York, pp. 277-293

Spurný P, Mareš J 1991: Fisheries aspects of operation in Dalešice water-works (the Jihlava river) (in Czech with English summary). Conference of Czechoslovak Limnological Society, Znojmo, pp. 188-191

Spurný P, Mareš J, Hedbávný J, Sukop I 2002: Heavy metal distribution in the ecosystems of the upper course of the Jihlava River. Czech J Anim Sci 47: 160-167

Svobodová Z, Vykusová B, Máchová J, Bastl J, Hrbková M, Svobodník J 1993: Pollutants monitoring in fish of the Labe River on the Celákovice locality (in Czech with English summary). Bull. of Research Institute of Fishery and Hydrobiology Vodňany pp. 47-61

Svobodová Z, Dušek L, Hejtmánek M, Vykusová B, Šmíd R 1999: Bioaccumulation of mercury in various fish species from Orlík and Kamýk water reservoirs in the Czech Republic. Ecotox Environ Safe 43: 231-240

Svobodová Z, Čelechovská O, Žlábek V 2004: Assessment of metal contamination in the upper reaches of the Tichá Orlice River. Czech J Anim Sci 49: 458-464

Thomas P 1990: Molecular and biochemical responses of fish to stressors and their potential as in environmental monitoring. Biological indicators of stress in fish. 8th American Fisheries Society Symposium, Maryland, pp. $9-28$

Vítek T, Spurný P, Mareš J, Ziková A 2007: Heavy metal contamination of the Loučka River water ecosystem. Acta Vet Brno 76: 149-154

Žlábek V, Svobodová Z, Randák T, Valentová O 2005: Mercury content in the muscle of fish from the Elbe River and its tributaries. Czech J Anim Sci 50: 528-534 